\title{
An Economic Analysis of Production Management of Watermelon in Haveri (Karnataka) and Ananthapur Districts (Andhra Pradesh) - A Comparative Analysis
}

\author{
Potnuru Santosh Kumar* and Vilas S. Kulkarni
}

Department of Agribusiness Management, University of Agricultural Sciences, Dharwad-580005, Karnataka, India

*Corresponding author

\begin{abstract}
A B S T R A C T
The present research entitled "An economic analysis of production management of watermelon in Haveri (Karnataka) and Ananthapur districts (Andhra Pradesh) - A comparative analysis" was carried out during the year 2017-18. For the study, 100 farmers were selected randomly from the study area. The main objectives of the study were to analyze the costs, returns and profitability of watermelon production in the study area. All

\section{Keywords}

Labour management, Input management, Cost of cultivation, Returns and profitability

Article Info

Accepted:

24 October 2018

Available Online:

10 November 2018

the farmers $(100 \%)$ in both the districts had sown seeds during rabi season and adopted drip irrigation for cultivating watermelon. Majority of the farmers in the study area used the inputs above the recommendation as per the package of practices for watermelon cultivation. Ananthapur district farmers applied more fertilizers compared to Haveri district farmers and with respect to plant protection chemicals (PPC) use was found to be high in Haveri district in comparison with Ananthapur district. The study revealed that watermelon cultivation is labour dependent and intensive, on an average 110 and 117 man days of labour were used in watermelon cultivation in Haveri and Ananthapur districts, respectively. The cost of cultivation is higher in the Ananthapur district farmers ( $₹$ 1, 43,306.17 / ha) compared to Haveri district ( $₹ 1,09,945.78$ / ha) farmers. The variation in cost of cultivation is due to Ananthapur farmers were spending more on seeds, neem cake and growth regulators. The gross returns obtained per hectare was more in Ananthapur district compared to Haveri district and the net returns obtained per hectare was more in Haveri district compared to Ananthapur district, because selling price per tonne was more in Haveri district. The cost and return analysis revealed that watermelon production in the study area was profitable with returns per rupee of investment (B: C ratio) of 1.79 and 1.58 .
\end{abstract}

\section{Introduction}

Watermelon (Citrullus lanatus) is one of the most important fruits cultivated in the tropics and consumed throughout the world. Watermelon is also known as tarbuj, tarmuj, kalingad and kalindi in different parts of India. Melons, as a general term, are sweet, juicy and tasty fruits being consumed mainly in the hot season and among the melons, two species, viz., watermelon [Citrullus vulgaris L. $\sin C$. lanatus (Thlumb) Mansf.] and muskmelon 
[Cucumismelo L.,], belonging to the Cucurbitaceae family. The global consumption of the fruit is greater than that of any other cucurbits. According to FAO (2016) statistics, world's largest producers of watermelon are China, Iran, Turkey, Brazil and the United States. In India area under watermelon was 95,520 hectares with a production of 23,62,160 tonnes in the year 2016-17. West Bengal is the leading producer of watermelon, where the area under watermelon is 16,540 hectares, followed by Uttar Pradesh (13,020 ha.), Karnataka and Odisha (11,730 ha. each), Andhra Pradesh $(8,520$ ha.) and Tamil Nadu (6,420 ha.). Total watermelon production in India during 201617 is $23,62,160$ metric tonnes, out of which Uttar Pradesh is leading in production with 5,86,610 metric tonnes followed by Karnataka (3,88,550 MT.), West Bengal (2,30,100 MT.), Odisha (2,26,640 MT.), Andhra Pradesh $(1,96,960$ MT.) and Tamil Nadu $(1,75,150$ MT.). (Anon., 2016a)

In Karnataka state, watermelon occupies 11,730 hectares and production was 3,88,550 metric tonnes; Mysore district is the leading producer of watermelon, where the area under watermelon is 1,490 hectares, followed by Haveri (1,430 ha.), Chamarajnagar (930 ha.), Kolar and Mandya (890 ha. each), Bagalkote (660 ha.), Kopppal (610 ha.), Belgavi (550 ha.) and Chikballapur (230 ha.) districts.

In Andhra Pradesh, total area and production under watermelon was 8,520 hectares and 2,37,890 metric tonnes; Anantapur district is the leading producer in the state, where the area under watermelon is 3,170 hectares, followed by Chittoor (2,200 ha.), Prakasam (530 ha.) and Kadapa (360 ha.) districts.

The comparative studies in two different locations can be very helpful in identifying alternative solutions that may be adopted by farmers, marketers and policy makers. This is other way to link more farmers, to reduce the spatial differences in the plain of production and marketing and it will narrow down the spatial price differences so that both consumers and producers will be benefited.

\section{Materials and Methods}

The study was conducted in Karnataka and Andhra Pradesh. For the present study, multistage sampling procedure was adopted. The first stage was comprised of selection of districts. Two districts, Haveri in Karnataka and Ananthapur in Andhra Pradesh were selected purposively based on the highest area and production of watermelon across the districts in Karnataka and Andhra Pradesh, respectively. In the second stage two taluks namely Hirekerur and Savanur were selected from Haveri district and two mandals namely Rapthadu and Ananthapur were selected for the study based on highest area in watermelon production.In the third stage, 25 farmers from each taluk and mandal were selected randomly from each district.

The study was based on primary data. The primary data were collected from the farmer respondents pertained to the agricultural year 2016-17, through personal interview method, with the help of well-structured and pre-tested questionnaire exclusively designed for the study. Tabular analysis was followed for analysis of the data.

\section{Results and Discussion}

\section{Production management aspects of watermelon in the study area}

Management aspects in the production of watermelon in the study area are depicted in the Table 1. It was observed that in Haveri district, 15 farmers $(30 \%)$ followed seed rate as per recommendation (875-1000 g/ha) and remaining 35 farmers $(70 \%)$ followed above 
the recommended seed rate. In Ananthapur district, 7 farmers (14\%) followed seed rate as per recommendation and remaining 43 farmers $(86 \%)$ followed more than the recommended seed rate respectively. All the respondents $(100 \%)$ in both the districts followed seed treatment. The seed treatment was done by the respective company itself.

Irrigation water was one of the major limited sources in the study area. Hence, irrigation management was one of the essential aspects in successful crop management. All the farmers $(100 \%)$ adopted drip irrigation system in both Haveri and Ananthapur districts. With respect to the nutrition management, all the respondents $(100 \%)$ in both the districts were using both organic and chemical fertilizers. It was observed that in Haveri district, 36 farmers (72\%) were using fertilizers above the recommendation and remaining 14 farmers (28 \%) were using fertilizers as per recommendation (100:80:80 NPK kg/ha). In Ananthapur district, 27 farmers (54\%) were using fertilizers above the recommendation, 21 farmers $(42 \%)$ were using fertilizers as per recommendation and remaining 2 farmers $(4 \%)$ were using fertilizers below the recommendation, respectively. All the farmers in Haveri and Ananthapur districts applied fertilizers in split doses. Half nitrogen, entire $\mathrm{P}$ and $\mathrm{K}$ were applied at the time of sowing. Rest of nitrogen was applied 45 - 50 days after sowing (DAS).

With respect to growth regulators, in Haveri district, the sample respondents didn't use any growth regulators, but at the time of fruit setting stage they were using $10 \mathrm{~g}$ multi $-\mathrm{K}$ per liter. In Ananthapur district 12 farmers (24 $\%)$ applied growth regulators below the recommended dose, 14 farmers $(28 \%)$ applied growth regulators above the recommendation and remaining 24 farmers (48 \%) applied growth regulators as per the recommendation, respectively. (1g NAA per 100 liters of water,
15 ppm $\mathrm{GA}_{3}$, cycocel as per package of practice for watermelon crop).

The table 1 also indicates that, with respect to pests and disease management in Haveri district most of the farmers i.e. 88 per cent (44 farmers) had adopted curative measures followed by preventive measures (12\%). Whereas, in Ananthapur district most of the farmers i.e. 90 per cent (45 farmers) had adopted curative measures and 10 per cent ( 5 farmers) had adopted preventive measures.

Proper stage of harvesting was very important as it determines the quality of fruits. The watermelon farmers in both the districts considered two criteria for deciding harvesting time; duration of the crop (90 to 110 DAS), colour and size of the fruit. As observed in Table 1, in Haveri district, most of the farmers i.e. 43 farmers $(86 \%)$ had adopted criteria of colour and size and remaining 7 farmers (14 $\%$ ) had adopted criteria of duration (90-110 DAS). Similarly, in Ananthapur district majority farmers i.e. 46 farmers $(92 \%)$ had adopted criteria of colour and size of the fruit and remaining 4 farmers $(8 \%)$ had adopted criteria of duration (90-110 days). With respect to number of pickings, all the sample farmers in both the districts followed more than one pickings ( 2 to 3 pickings per crop).

Majority of the farmers in both the study districts used inputs above the recommendation as per the package of practices for watermelon cultivation. From the farmers point of view they seem to be right on using highest input rates to confirm themselves to get better plant population, which will definitely influence on total production. On the other hand they have to be very cautious while using the excess rate, because inputs are very costly and which will unnecessarily add to the total cost, in turn effecting on the net returns. Most of the sample farmers in Haveri and Ananthapur 
districts (88\% and $90 \%$ ) followed curative measures for pest and disease management. Watermelons are not prone to pests and diseases to a longer extent. Hence, no need of preventive measures, only certain curative measures as and when pest and disease incidence occurs is enough.

\section{Labour management in watermelon cultivation in the study area}

An operation-wise labour requirement in watermelon cultivation was calculated in Haveri and an Ananthapur districts and the results were depicted in Table 2. The results indicated that, the average human labour employed in Haveri district were 109.68 man days out of which 41.04 man days $(37.42 \%)$ were family labour and rest 68.64 man days $(62.58 \%)$ were hired labour. Maximum number of man days were employed for intercultural operations such as weeding, thinning and apical shoot removing etc., (24.89\%), followed by harvesting (15.09\%), PPC application (10.61\%), sowing (10.32\%), mulching (8.91 \%), manuring (8.29\%), fertilizer application $(8.27 \%)$, maintenance of drip irrigation channels (4.83\%), gap filling $(2.91 \%)$, bed preparation $(2.18 \%)$, earthing up $(1.82 \%)$, ploughing $(0.92 \%)$ and harrowing (0.92\%), respectively. Similarly, in Ananthapur district, the average human labour employed were 117.35 man days, out of which 41.40 man days $(35.28 \%)$ were family labour and rest 75.95 man days (64.72\%) were hired labour. Maximum number of man days was employed for intercultural operations (21.53 $\%)$, followed by sowing (13.71\%), harvesting (12.68 \%), mulching (10.90\%), PPC application (10.36\%), manuring (9.65\%), fertilizer application $(8.41 \%)$, maintenance of drip irrigation channels (4.26\%), gap filling $(3.11 \%)$, bed preparation $(1.94 \%)$, earthing up $(1.70 \%)$, ploughing $(0.86 \%)$ and harrowing $(0.86 \%)$, respectively.
In Haveri district, bullock labours (4.18 pair days) were employed only for earthing up operation $(100 \%)$. Whereas in Ananthapur district, maximum of bullock pair days (4.32) were employed for earthing up operations (71.52\%), followed by intercultural operations (1.72 pair days). The average machine labour employed in Haveri district were 6.04 hours of which 38.24 per cent of machine hour were employed for ploughing, followed by bed preparation (30.96\%) and harrowing (30.79 $\%)$. In Ananthapur district the average machine labour employed were 8.06 hours.

Maximum number of machine hours was employed for ploughing (33.87\%), followed by harrowing $(33.13 \%)$ and bed preparation $(33.00 \%)$. It is interesting to note that despite the use of bullock labour, machine labour was most common for land preparation. Majority of the farmers used hired tractor hours for field preparation.

Watermelon is highly labour intensive crop as compared to other field crops. Hence, advocating machine labour in place of human labour would not only reduce the cost of cultivation but also reduce the pressure of human labour on land which has become very active because of scarcity of labour in recent times. The study reveals that on an average 110 and 117 man days of labour were used in watermelon cultivation in Haveri and Ananthapur districts, respectively.

\section{Input management in watermelon cultivation in the study area}

In any cultivation, input management assumes a critical importance. Input use pattern in watermelon production in Haveri and Ananthapur districts is depicted in Table 3. The results show that, in Haveri and Ananthapur districts the overall seed rate used for sowing were $1,211 \mathrm{~g}$ and $1,057 \mathrm{~g}$ per hectare, respectively. 
Table.1 Production management aspects of watermelon in the study area

\begin{tabular}{|c|c|c|c|c|c|c|}
\hline $\begin{array}{l}\text { Sl. } \\
\text { No }\end{array}$ & Particulars & Units & $\begin{array}{l}\text { Haveri } \\
\text { district } \\
(n=50)\end{array}$ & $\%$ & $\begin{array}{l}\text { Ananthapu } \\
\text { r district } \\
(n=50)\end{array}$ & $\%$ \\
\hline 1 & Seed rate/ha & No's & & & & \\
\hline a. & Below recommendation & & - & - & - & - \\
\hline b. & As per recommendation & & 15 & 30.00 & 7 & 14.00 \\
\hline c. & Above recommendation & & 35 & 70.00 & 43 & 86.00 \\
\hline 2 & Seed treatment & No's & 50 & $\begin{array}{c}100.0 \\
0\end{array}$ & 50 & $\begin{array}{c}100.0 \\
0\end{array}$ \\
\hline 3 & Irrigation management & No's & & & & \\
\hline$\overline{\text { a. }}$ & Drip method & & 50 & $\begin{array}{c}100.0 \\
0\end{array}$ & 50 & $\begin{array}{c}100.0 \\
0\end{array}$ \\
\hline b. & Flood method & & - & - & - & - \\
\hline c. & Traditional methods & & - & - & - & - \\
\hline 4 & Nutrition management & No's & & & & \\
\hline a. & Type of fertilizer used & & - & - & - & - \\
\hline i. & Organic & & - & - & - & - \\
\hline ii. & Chemical & & - & - & - & - \\
\hline iii. & Organic and chemical & & 50 & $\begin{array}{c}100.0 \\
0\end{array}$ & 50 & $\begin{array}{c}100.0 \\
0\end{array}$ \\
\hline b. & Fertilizer dose & & & & & \\
\hline i. & Below recommendation & & - & - & 2 & 4.00 \\
\hline ii. & As per recommendation & & 14 & 28.00 & 21 & 42.00 \\
\hline iii. & Above recommendation & & 36 & 72.00 & 27 & 54.00 \\
\hline c. & $\begin{array}{l}\text { Method of fertilizer } \\
\text { application }\end{array}$ & & & & & \\
\hline i. & Single dose application & & - & - & - & - \\
\hline ii. & Split dose application & & 50 & $\begin{array}{c}100.0 \\
0\end{array}$ & 50 & $\begin{array}{c}100.0 \\
0\end{array}$ \\
\hline 5. & Growth regulators & No's & & & & \\
\hline a. & $\begin{array}{l}\text { Not used \& Below } \\
\text { recommendation }\end{array}$ & & 50 & $\begin{array}{c}100.0 \\
0\end{array}$ & 12 & 24.00 \\
\hline b. & As per recommendation & & - & - & 24 & 48.00 \\
\hline c. & Above recommendation & & - & - & 14 & 28.00 \\
\hline 6. & $\begin{array}{l}\text { Pest and Disease } \\
\text { management }\end{array}$ & No's & & & & \\
\hline a. & Preventive measures & & 6 & 12.00 & 5 & 10.00 \\
\hline b. & Curative measures & & 44 & 88.00 & 45 & 90.00 \\
\hline c. & IPM & & - & - & - & - \\
\hline 7. & Criteria for harvesting & No’s & & & & \\
\hline a. & 90 -110 Days after sowing & & 7 & 14.00 & 4 & 8.00 \\
\hline b. & Colour and size & & 43 & 86.00 & 46 & 92.00 \\
\hline
\end{tabular}


Table.2 Labour management in watermelon cultivation in the study area

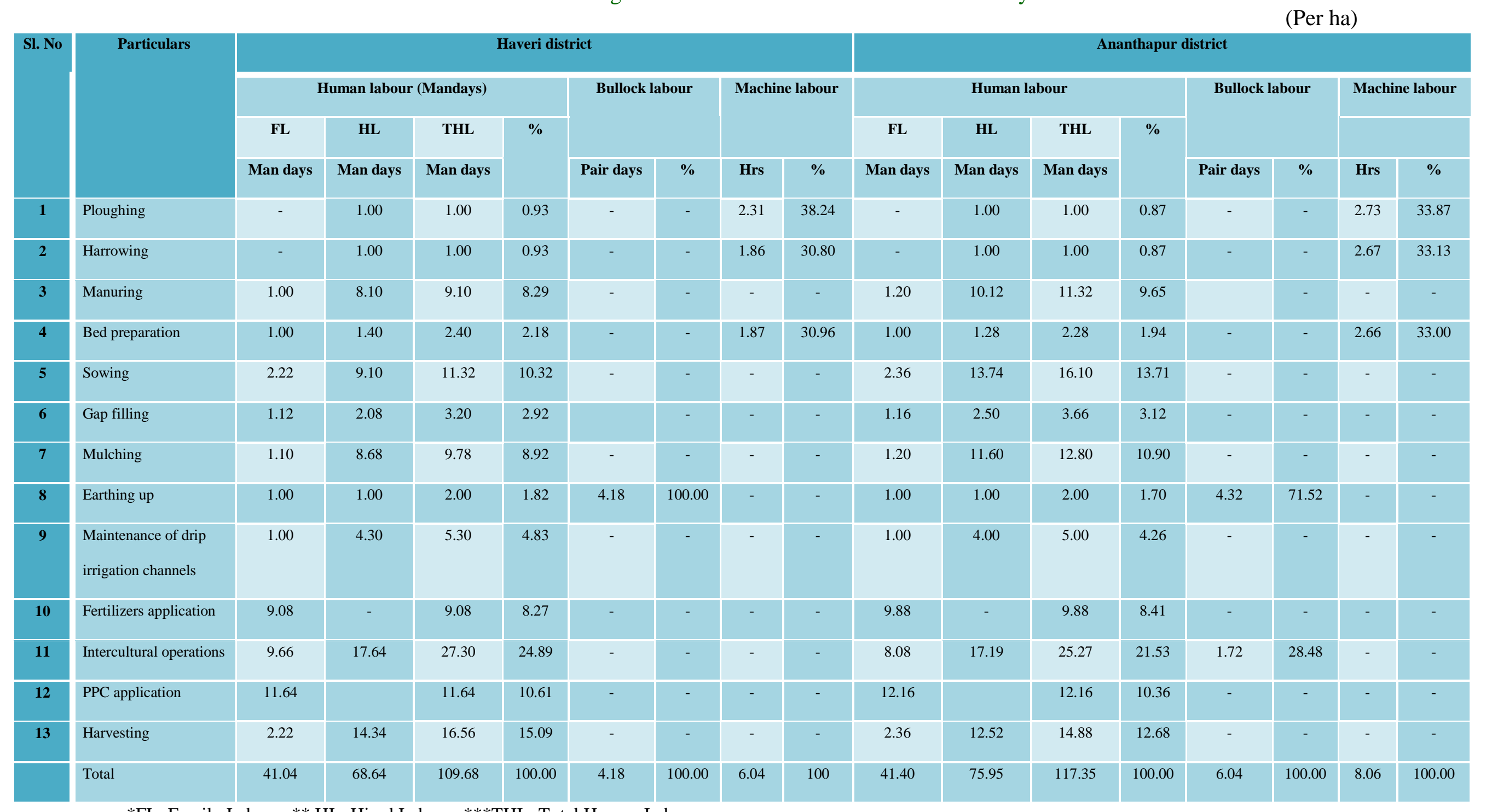

*FL: Family Labour; ** HL: Hired Labour; ***THL: Total Human Labour 
Table.3 Input management in watermelon cultivation in the study area

\begin{tabular}{|c|c|c|c|c|}
\hline Sl. No & Particulars & Units & Haveri District & Ananthapur district \\
\hline 1 & Seeds & $\mathrm{G}$ & 1,211 & 1,057 \\
\hline 2 & FYM & Tonnes & 5.58 & 9.73 \\
\hline 3 & Neem cake & $\mathrm{Kg}$ & - & 338.00 \\
\hline \multirow[t]{4}{*}{4} & Major nutrients & & & \\
\hline & i. $\quad$ Nitrogen $(\mathrm{N})$ & $\mathrm{Kg}$ & 102.82 & 114.68 \\
\hline & Phosphorous (P) & $\mathrm{Kg}$ & 143.03 & 122.63 \\
\hline & i. $\quad$ Potash $(\mathrm{K})$ & $\mathrm{Kg}$ & 129.70 & 121.72 \\
\hline \multirow[t]{4}{*}{5} & Micro nutrients & & & \\
\hline & i. $\quad$ Calcium $(\mathrm{Ca})$ & $\mathrm{Kg}$ & 00.45 & 17.68 \\
\hline & Sulphur (S) & $\mathrm{Kg}$ & 14.56 & 32.88 \\
\hline & Boron (B) & $\mathrm{G}$ & 287.70 & 266.70 \\
\hline \multirow[t]{4}{*}{6} & PPC & & & \\
\hline & Granules & $\mathrm{Kg}$ & 9.48 & 6.52 \\
\hline & Wettable powder & $\mathrm{Kg}$ & 6.93 & 6.52 \\
\hline & i. $\quad$ Solvents & $\mathrm{kg}$ & 6.99 & 6.71 \\
\hline 7 & Growth regulators & $\mathrm{g}$ & - & 116.00 \\
\hline 8 & Herbicides & litres & 1.86 & 4.02 \\
\hline 9 & Drip laterals & $\mathrm{m}$ & 5270.68 & 5141.00 \\
\hline 10 & Mulching sheet & rolls & 12.00 & 11.94 \\
\hline 11 & Human labour & man days & 109.68 & 117.35 \\
\hline 12 & Bullock labour & pair days & 4.18 & 6.04 \\
\hline 13 & Machine labour & hours & 6.04 & 8.06 \\
\hline
\end{tabular}

Table. 4 Cost of cultivation of watermelon in the study area

\begin{tabular}{|c|c|c|c|c|c|}
\hline SI. No. & Particulars & $\begin{array}{l}\text { Haveri } \\
\text { district } \\
(\mathrm{n}=50)\end{array}$ & $\%$ & $\begin{array}{c}\text { Ananthapur } \\
\text { district } \\
(\mathrm{n}=50)\end{array}$ & $\%$ \\
\hline & Variable cost & & & & \\
\hline 1. & Seeds & $11,715.00$ & 10.66 & $26,971.74$ & 18.83 \\
\hline 2. & Farm yard manure (FYM) & $3,236.40$ & 2.94 & $5,998.50$ & 4.19 \\
\hline 3. & Neem cake & - & - & $11,830.02$ & 8.26 \\
\hline 4. & Human labour & $24,129.60$ & 21.95 & $23,752.10$ & 16.57 \\
\hline 5. & Bullock labour & $1,463.00$ & 1.33 & $2,260.00$ & 1.57 \\
\hline 6. & Machine labour & $2,416.00$ & 2.20 & $2,821.00$ & 1.96 \\
\hline 7. & Herbicides & $1,024.10$ & 0.93 & $1,040.40$ & 0.73 \\
\hline 8. & Chemical Fertilizers & $11,579.00$ & 10.53 & $12,079.80$ & 8.44 \\
\hline 9. & Micro nutrients & $2,475.70$ & 2.25 & $1,848.10$ & 1.28 \\
\hline 10. & Plant protection chemicals (PPC) & $13,984.24$ & 12.71 & $15,027.04$ & 10.48 \\
\hline 11. & Growth regulators & - & - & $2,219.48$ & 1.55 \\
\hline 12. & Mulching sheet & $7,200.00$ & 6.55 & $7,390.14$ & 5.15 \\
\hline 13. & Drip irrigation structures & $5,270.68$ & 4.79 & $3,698.44$ & 2.58 \\
\hline \multirow[t]{3}{*}{14.} & Interest on working capital @8\% per annum & $6,759.50$ & 6.15 & $8,467.85$ & 5.91 \\
\hline & Subtotal (A) & $91,253.22$ & 82.99 & $1,25,404.21$ & 87.50 \\
\hline & B. $\quad$ Fixed cost & & & & \\
\hline 15. & Rental value of land & $11,550.00$ & 10.50 & $10,400.00$ & 7.25 \\
\hline 16. & Land revenue & 50.00 & 0.04 & 200.00 & 0.15 \\
\hline 17. & Depreciation & $5,089.79$ & 4.64 & $5,383.90$ & 3.76 \\
\hline \multirow[t]{3}{*}{18.} & Interest on fixed capital @12\% per annum & $2,002.77$ & 1.83 & $1,918.06$ & 1.34 \\
\hline & Subtotal (B) & $18,692.56$ & 17.01 & $17,901.96$ & 12.50 \\
\hline & Total cost of cultivation $(\mathrm{A}+\mathrm{B})$ & $1,09,945.78$ & 100.00 & $1,43,306.17$ & 100.00 \\
\hline
\end{tabular}


Table.5 Cost and returns of watermelon production in the study area

\begin{tabular}{|c|l|c|c|}
\hline S. No & \multicolumn{1}{|c|}{ Particulars } & $\begin{array}{c}\text { Haveri } \\
\text { district }\end{array}$ & $\begin{array}{c}\text { Ananthapur } \\
\text { district }\end{array}$ \\
\hline 1. & Yield (tonnes) & 27.50 & 36.62 \\
\hline 2. & Total cost of cultivation(₹) & $1,09,945.78$ & $1,43,306.17$ \\
\hline 3. & Selling price (₹/tonne) & $7,183.00$ & $6,175.00$ \\
\hline 4. & Gross returns (₹) & $1,97,532.50$ & $2,26,128.50$ \\
\hline 5. & Net returns (₹) & $87,586.72$ & $82,822.33$ \\
\hline 6. & B:C ratio & & 1.58 \\
\hline
\end{tabular}

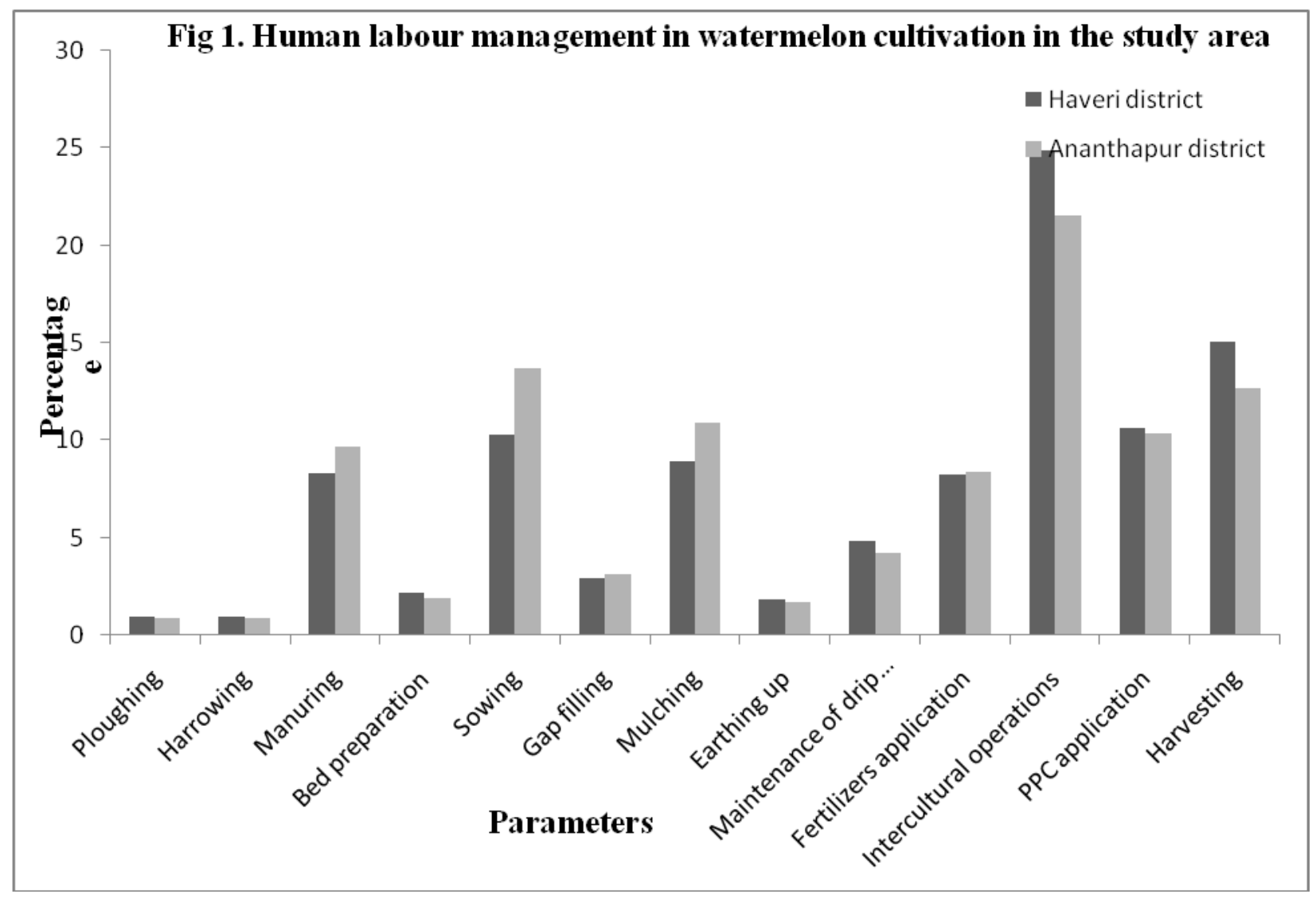




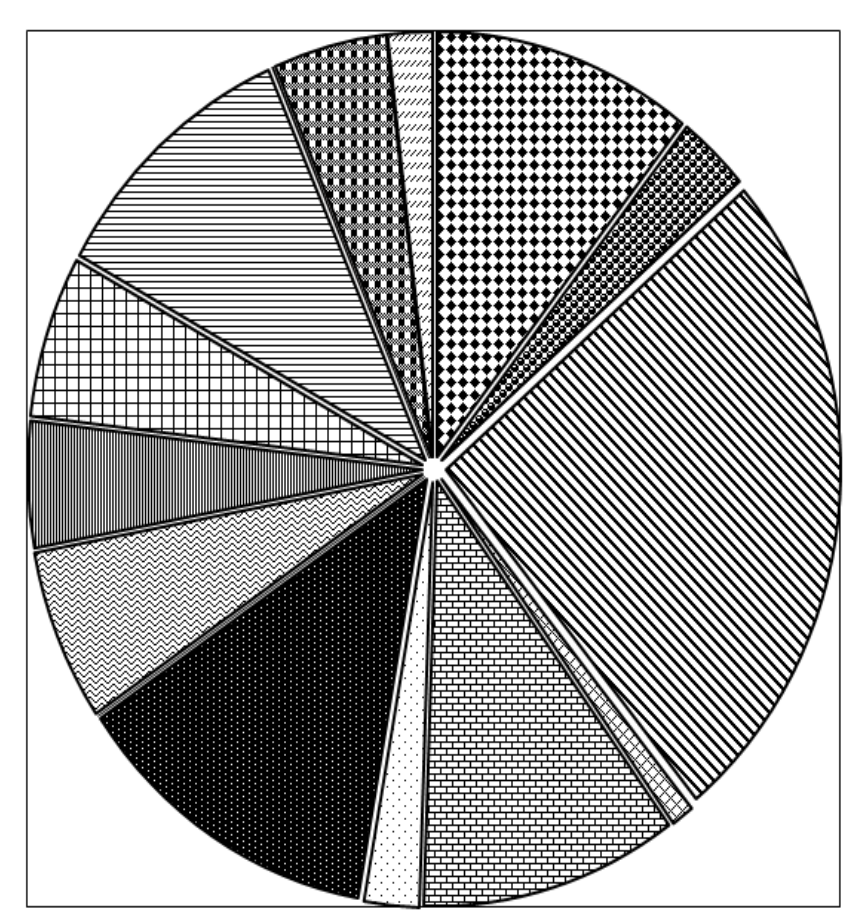

Heeds

Farm yard manure (FYM)

$\square$ Neem cake

\$Labour

因Herbicides

国Chemical Fertilizers

$\square$ Micro nutrients

Plant protection chemicals (PPC)

$\square$ Growth regulators

圂Mulching sheet

四Drip irrigation structures

ت⿴囗十terest on working capital @8\% per annum

$\boxminus$ Rental value of land

\section{$\square$ Land revenue}

Depreciation

שInterest on fixed capital @12\% per annum

Fig. 2. Cost of cultivation of watermelon in Haveri district

(Karnataka) 


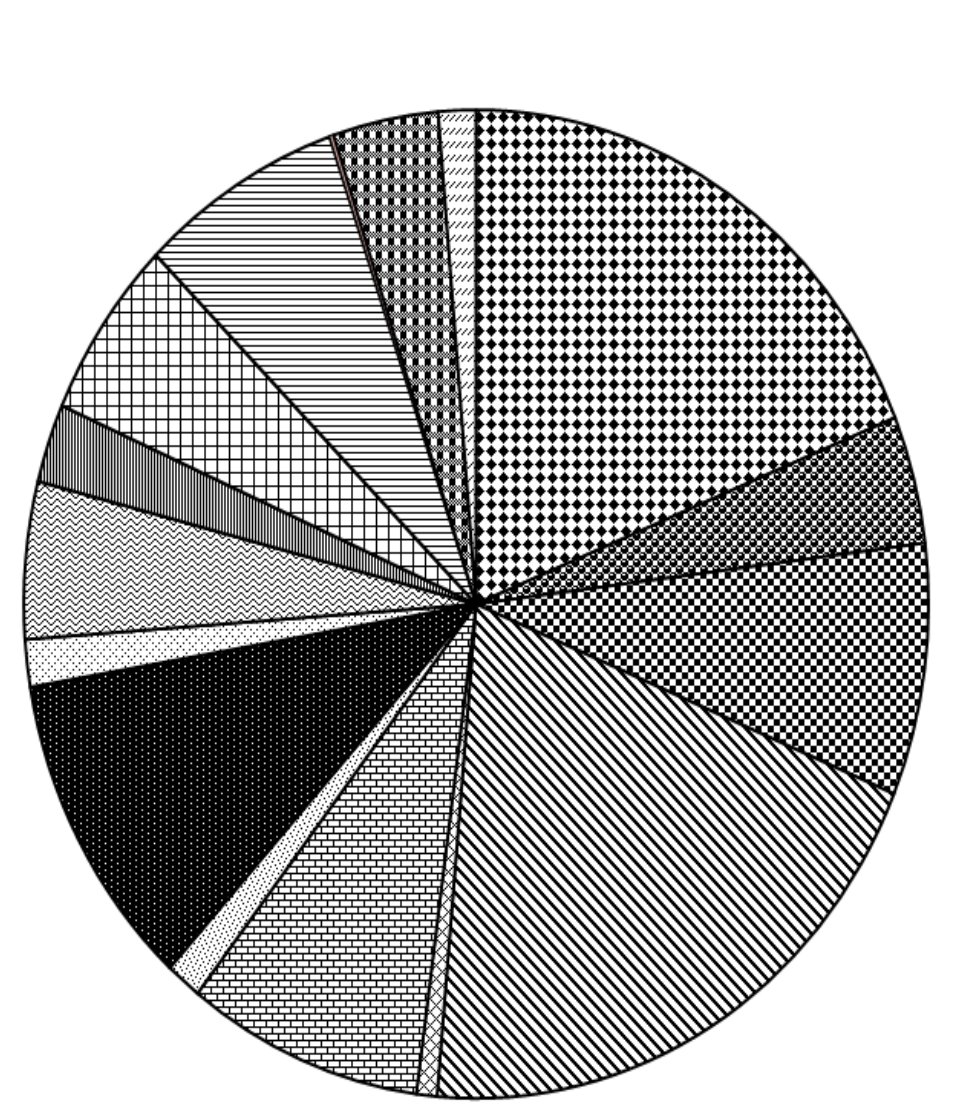

Seeds

Farm yard manure (FYM)

Neem cake

$\boldsymbol{\nabla}$ Labour

8 Herbicides

\$ Chemical Fertilizers

圆 Micro nutrients

Plant protection chemicals (PPC)

Growth regulators

Mulching sheet

四 Drip irrigation structures

由Interest on working capital @8\% per annum

目 Rental value of land

$\square$ Land revenue

Depreciation

Interest on fixed capital @12\% per annum

Fig. 3. Cost of cultivation of watermelon in Ananthapur district (Andhra Pradesh) 
The quantity of FYM applied in Haveri district were 5.58 tonnes per hectare and in Ananthapur district the quantity of FYM applied were 9.73 tonnes per hectare. In Haveri district the sample respondents didn't use neem cake for cultivation of watermelon, while in Ananthapur district, the average quantity of neem cake applied per hectare were $338 \mathrm{~kg}$.

With respect to major nutrients, the quantity of $\mathrm{N}, \mathrm{P}$ and $\mathrm{K}$ applied in Haveri district were $102.82,143.03$ and $129.70 \mathrm{~kg}$ per hectare respectively. Similarly, in Ananthapur district, the amount of $\mathrm{N}, \mathrm{P}$ and $\mathrm{K}$ used were 114.68, 122.63 and $121.72 \mathrm{~kg}$ per hectare, respectively. With respect to micro nutrients, the quantity of Calcium (Ca) and Sulphur (S) applied in Haveri district were 0.45 and $14.56 \mathrm{~kg}$ per hectare respectively, while in Ananthapur district the quantity of the same were 17.68 and $32.88 \mathrm{~kg}$ per hectare, respectively. The quantity of Boron (B) applied in Haveri and Ananthapur districts were 287.70 and $266.70 \mathrm{~g}$ per hectare. In Haveri district, the average quantity of plant protection chemicals used were $9.48 \mathrm{~kg}$ granules, $6.93 \mathrm{~kg}$ wettable powder and 6.99 liters of chemical solvents. Similarly, in Ananthapur district the average quantity of plant protection chemicals used were $6.52 \mathrm{~kg}$ granules, $6.52 \mathrm{~kg}$ wettable powder and 6.71 liters of chemical solvents respectively. In Ananthapur district, the average quantity of growth regulators used per hectare was $116 \mathrm{~g}$. whereas, in Haveri district the sample respondents didn't use any growth regulators.

In Haveri and Ananthapur districts, the average quantity of pre-emergence herbicides used were 1.86 and 4.02 liters per hectare respectively. With respect to drip irrigation laterals, the average amount of laterals used in both the districts were 5270.68 meters and 5141.00 meters respectively. The average amount of mulching sheet used in Haveri district were 12.00 rolls and in Ananthapur district were 11.94 rolls.

The average amount of human, bullock and machine labour employed in Haveri district were 109.68 man days, 4.18 pair days and 6.04 machine hours respectively and in Ananthapur district, the average amount of human, bullock and machine labour employed were 117.35 man days, 6.04 pair days and 8.06 machine hours respectively.

In Haveri district, the farmers used around 200 $\mathrm{g}$ more seeds as compared to farmers of Ananthapur district. Normally 875 to $1000 \mathrm{~g}$ of seeds are required for planting one hectare of area in case of hybrids. The utilization of seeds depends on the spacing and type of planting in the field. Non usage of neem cake and growth regulators on part of Haveri farmers may be due to the lack of awareness of benefits of neem cake application. Hence, there is a need to educate the watermelon farmers of Haveri district in this regard. The amount of fertilizer applied in Haveri and Ananthapur districts during cropping time indicated that Ananthapur district farmers applied more fertilizers compared to Haveri district farmers. Plant protection chemicals (PPC) use was found to be high in Haveri district in comparison with Ananthapur district. In both the districts, watermelon cultivation was done by using drip irrigation and mulching technique was used to control the weeds as well as increasing the water use efficiency (WUE), because, both districts belongs to dry land areas. The total human labour, bullock labour and machine labour employed were more in Ananthapur district than in Haveri district.

\section{Cost of cultivation of watermelon in the study area}

The cost of cultivation indicates the investment on the variable inputs used in the cultivation and the services rendered by fixed assets. The cost incurred on inputs and returns realized from watermelon cultivation were calculated and are shown in Table 4 and 5. The total cost incurred by the sample farmers for per hectare cultivation in Haveri and Ananthapur districts were ₹ $1,09,945.78$ and ₹1,43,306.17 respectively. In Haveri district, the share of total variable cost was 82.99 per cent in the total 
cost. The distribution pattern of operational cost under various inputs indicated that the human labour accounted for highest share $(21.95 \%)$ followed by PPC (12.71 \%), seeds (10.66\%), macro nutrients $(10.53 \%)$, mulching sheet $(6.55 \%)$, drip irrigation structures $(4.79 \%)$, FYM (2.94 \%), micro nutrients (2.25\%), machine labour $(2.20 \%)$, bullock labour (1.33 $\%)$ and herbicides $(0.93 \%)$, respectively. Similarly, in Ananthapur district, the share of total variable cost was 87.50 per cent in the total cost. The distribution pattern of operational cost under various inputs indicated that the seeds accounted for highest share $(18.83 \%)$ in the case of variable cost followed by human labour (16.57 \%), PPC (10.48 \%), macro nutrients $(8.44 \%)$, neem cake $(8.26 \%)$, mulching sheet (5.15 \%), FYM (4.19 \%), drip irrigation structures $(2.58 \%)$, machine labour $(1.96 \%)$, bullock labour $(1.57 \%)$, growth regulators $(1.55 \%)$ and micro nutrients $(1.28 \%)$, respectively.

In Haveri district, the share of total fixed cost was 17.01 per cent in the total cost. The distribution pattern of fixed cost under various inputs indicated that the rental value of land accounted for highest share $(10.50 \%)$ followed by depreciation (4.64 \%) and land revenue (0.04 $\%$ ), respectively. Similarly, in Ananthapur district, the share of total fixed cost was 12.50 per cent in the total cost. The distribution pattern of fixed cost under various inputs indicated that the rental value of land accounted for highest share $(7.25 \%)$ in case of fixed cost followed by depreciation $(3.76 \%)$ and land revenue $(0.15 \%)$, respectively.

The results presented in Table 5 on yield and returns realized by the watermelon cultivated farmers indicated that the average yield of the watermelon in both the districts were 27.50 and 36.62 tonnes per hectare. In Haveri and Ananthapur districts, the gross returns obtained per hectare were ₹ 1, 97,532.50 and ₹2, 26, 128.50 respectively. Total cost of cultivation in both the districts was ₹1, 09,945.78 and ₹1, 43,306.17 respectively. The net returns obtained per hectare in both the districts were ₹87,
586.72 and $₹ 82,822.33$ respectively. Thus, cultivation of watermelon in both the districts was found to be profitable by magnitude of $\mathrm{B}$ : $\mathrm{C}$ ratio (returns per rupee of investment) of 1.79 and 1.58 , respectively.

The average total cost incurred by the Ananthapur district farmers were found to be higher (₹ 1, 43,306.17 / ha) compared to Haveri district (₹ 1, 09,945.78 / ha) farmers. This might be attributable to the fact that Ananthapur district farmers used more inputs like seeds, human, bullock and machine labour, neem cake and applied more fertilizer than their counterparts. The distribution pattern of operational cost under various inputs between the districts revealed that cost of seeds, FYM, neem cake and growth regulators were more in Ananthapur district as compared to Haveri district. Contrary to it the expenditure on fertilizers and micronutrients was more in Haveri district ( $₹ 14,054.70$ / ha) compared to Ananthapur district (₹ 13,927.90 / ha).

It was observed from the table 5, that the average selling price per tonne was more in Haveri district compared to Ananthapur district, because of high demand and less supply of watermelon in Karnataka. The average gross returns obtained per hectare was more in Ananthapur district compared to Haveri district only due to high yield per hectare. The average net returns obtained per hectare was more in Haveri district compared to Ananthapur district, because selling price per tonne was more in Haveri district. In both the districts, the net returns realized by the respondents from cultivation of watermelon worked out with returns per rupee of investment (B: $\mathrm{C}$ ratio) of 1.79 and 1.58. This indicates that cultivation of watermelon is a profitable agribusiness enterprise.

From the findings of the study following conclusion has been derived. It is observed from the study that, all the respondents have changed their mind and adopted hybrids of watermelon, as they observed that, growing of these seeds are profitable, resistant to disease and pests, 
yield is higher and early maturity in comparison to local variety of watermelon. Watermelon is highly labour dependent crop and requires more labour than the cereals and pulses. It reveals that on an average 110 and 117 man days of labour were used in watermelon cultivation in Haveri and Ananthapur districts, respectively. The cost of cultivation is maximum in the Ananthapur district farmers (₹ 1, 43,306.17 / ha) compared to Haveri district (₹ 1, 09,945.78 / ha) farmers. The cost and return analysis revealed that watermelon production in the study area was profitable with returns per rupee of investment (B: C ratio) of 1.79 and 1.58.

\section{References}

Ahmad, A., Prasad, L. P., Dinesh, K., Nahar, S., Prasad, V. M. and Anupriya, P., 2017. An economic analysis of production of watermelon in Allahabad district, UP, India. International Journal of Advanced Education and Research. 2(4): 206-210.

Amutha, D., 2014. An analysis of sapota fruit cultivation in Tuticorin district, India. International Journal of Economics and Management Sciences. 3(4): 1-4.

Bondar, U. S., Daundkar, K. S. and Khedkar, S. R., 2015. Economics of production of banana in Kolhapur district of Maharashtra. International Research Journal of Agricultural Economics and Statistics. 6(2): 336-341.

Datarkar, S. B., Darekar, A. S., Dangore, U. T. and Parshuramkar, K. H., 2014.
Economics of production and marketing of mango in Gadchiroli district of Maharashtra. International Research Journal of Agricultural Economics and Statistics. 5 (2): 278-283.

Dhuri, S. S., Jadhav, M, S. and Misal, S, J., 2017. Economics of production of alphonso mango in Sindhudurg district of Maharashtra. InternationalJournal of Chemical Studies. 5(4): 544-549.

Jain, B. C. and Tegar, A., 2003, Economics of production and marketing of tomato in Jashpur district of Chhattisgarh. Agricultural Marketing. 46(3): 5-10.

Pokharkar, V. G., Sangle, S. A. and Kulkarni, A. R., 2016. Economics of production and marketing of guava in western Maharashtra. International Research Journal of Agricultural Economics and Statistics. 7(2): 234-242.

Ropan, B., Sarju, P. and Ravi, S., 2015. Economics of orange production in Nagpur district of Maharashtra. International Research Journal of Agricultural Economics and Statistics. 6(1): 136-139.

Vairam, R. and Muniyandi, B., 2013. Production and marketing of grape cultivation in Theni district, Tamil Nadu. International Journal of Research in Commerce, Economics and Management. 3(9): 2231-2245.

\section{How to cite this article:}

Potnuru Santosh Kumar and Vilas S. Kulkarni. 2018. An Economic Analysis of Production Management of Watermelon in Haveri (Karnataka) and Ananthapur Districts (Andhra Pradesh) - A Comparative Analysis. Int.J.Curr.Microbiol.App.Sci. 7(11): 2945-2957. doi: https://doi.org/10.20546/ijcmas.2018.711.337 